\title{
The Ability of Managerial Ownership Moderating of The Effect of Enterprise Risk Management (ERM) Disclosure Toward The Company Value
}

\author{
${ }^{1}$ Ni Luh De Erik Trisnawati, ${ }^{2}$ Eddy Supriyadinata Gorda, ${ }^{3}$ Ni Kadek Ayu Trisnadewi \\ niluhdeeriktrisna@gmail.com, Eddy_supriyadinata@yahoo.com, aayu.trina.22@gmail.com \\ ${ }^{1,3}$ STIE Satya Dharma Singaraja, ${ }^{2}$ Universitas Pendidikan Nasional
}

\begin{abstract}
This study aims to test and prove managerial ownership to moderate the relationship of Enterprise Risk Management (ERM) disclosure toward the company value. The management always tried to reveal private information, especially good news which according to the consideration of the company was very interested by the investors and shareholders. This research will be conducted on public companies and published annual report in 2014-2016. This research was using purposive sampling technique so that obtained 57 data observation. Moderated Regression Analysis (MRA) with panel data regression models are used to analyze data. The results showed that ERM disclosure had no effect on company value. The relationship between ERM disclosures to company value is also not able to be moderated by managerial ownership.
\end{abstract}

Keywords: ERM disclosure, Managerial ownership, corporate value.

\section{Introduction}

The establishment of a company aims to maximize the prosperity of business owners (Murtini 2008). The high value that can be achieved by a company is one way to maximize the prosperity of business owners. Enterprise Risk Management (ERM) that is applied by companies and disclosed to the public is of course a weapon to encourage companies to achieve higher values. Currently in addition to financial information contained in the company's annual report of public concern, nonfinancial information is also a public concern is ERM. This information begins to be of concern when investors have difficulty in providing valuations to decide on their investment, because in the end some companies that always provide good financial information have not guaranteed the company is free from fraud (Devi, 2017). This condition is then reinforced by the reappearance of fraud cases in 2017 that occurred in large multinational company British Telecom after previously happened to some big companies like case of Worldcom and Thosiba. British Telecom experienced accounting fraud in one of its business lines in Italy. This accounting fraud scandal impacted shareholder and investor losses in which British Telecom's share price plummeted by one-fifth when British Telecom announced its earnings correction.

These events further prove that financial information will not be able to be the sole basis of investment decision assessment. According to Holland (2002) to assess a company needed other information in addition to information that is financial. The high risks inherent in investment activities cause investors to require ERM information that can assist them in 
assessing the company not only now but also the company's future condition. Companies that are able to properly manage risk in the form of ERM implementation and disclose it to the public are likely to be responded better by investors.

The disclosure of corporate risk management, hereinafter referred to as ERM disclosure, presents the company's risk management information including the impact of such risks in the future. This information is presented as a signal that the company has a high commitment in risk management including its impact on the company (Hoyt and Liebenberg 2011). Hoyt \& Liebenberg in his research in 2008 found that ERM implementation in the company can help company to inform external parties related to the company's risk profile. In 2011 Tahir and Razali found that the value of the company did not significantly increase after the company implemented ERM.

While Bertinetti et al. (2013) actually finds ERM disclosure positively affects the value of the company. Mulyasari, et al who conducted a study in 2013 found that corporate value can also be maximized through ERM, but the real impact of the implementation of the ERM does not yet seem significant. Different results were found in the same year by Sanjaya and Linawati that there is no relationship between companies that implement ERM on increasing corporate value. Devi (2017) found ERM disclosure can increase the value of a company. Results of research conducted by some previous researchers are still inconsistent. According to Devi (2017) more and more items in ERM dimensions are disclosed is a signal company for the investor to the company rated higher. In real terms, not all companies that make voluntary disclosure are considered positive by investors (Abdullah et al., 2015). Companies that disclose risk information that is perceived to threaten the sustainability of their business in the future are not responded by the public or investors.

The regulation ERM disclosure in indonesia does not mention the extent of its disclosure. So even though ERM is not disclosed by the company has not detailed in its financial statements. In line with Syifa's (2013) research on manufacturing firms in Indonesia listed on IDX on ERM, Syifa explained that the company's response to ERM implementation and disclosure is still low. Syifa (2013) also found from all manufacturing companies under study there are still companies that have not applied ERM. The results of the research on inconsistent ERM disclosure led to this interesting research to be researched in Indonesia, especially for manufacturing companies.

The findings of inconsistent research findings, particularly in manufacturing companies, suggest that there may be other variables that affect the ERM disclosure relationship to firm value. According to agency theory to reduce conflicts that may occur in companies whose management functions and ownership functions are separated can be done by involving managers in share ownership (Imanta, 2011). With stakeholder involvement, managers are expected to act by taking into account any existing risks and motivate themselves to improve their performance in managing the company (Ningsih, 2013). Companies that are able to demonstrate a high commitment to risk management through a quality disclosure ERM that is managed by managers who are also shareholders will be more responded by investors.

Research on ERM disclosure associated with firm value using managerial ownership as a moderating variable in manufacturing companies is still not being done in Indonesia so it still needs to be proven empirically in order to raise awareness for better risk management and perform better quality disclosure ERM. This research is focused on manufacturing company because based on result of Syifa (2013) research that company's response to ERM 
implementation and disclosure is still low even there is still not applying ERM so this research is done to prove empirically managerial ownership role in moderating influence of ERM disclosure in increasing value companies in manufacturing companies.

\section{Literature Review}

Stakeholder theory encourages management to conduct management activities through the maximization of economic resources so as to encourage the achievement of the maximum value of the company in accordance with the expectations of stakeholders. While signalling theory states management will attempt to convey information even though the information is not required. Ho and Wong (2001) explains that efforts can be made through voluntary disclosure while according to Ramadhani (2012) through increased managerial ownership. Voluntary disclosure that is able to provide important information for investors is ERM disclosure. ERM disclosure will provide information on not only the risks that the company has managed but including the company's efforts in controlling those risks. ERM disclosure began to be published by COSO in 2004 as an effort to achieve company goals. COSO formulates the ERM framework that is implemented into each enterprise strategy through eight dimensions with 108 items consisting of (1) internal environment, (2) goal setting, (3) identification of events, (4) risk assessment, (5) response (6) monitoring activities, (7) information and communication, and (8) monitoring (Meizaroh and Lucyanda 2011). In response to the ERM framework published by COSO, Indonesia's regulatory body in 2010 which was revised in 2012 also issued a regulation on risk management disclosure. The regulation is governed by PSAK No. 60 (Revised 2010 on Financial Instruments) and Decree LK Number: Kep-431 / BL / 2012 issued by the Chairperson of Bapepam regarding the mandatory regulation of risk explanation and risk management efforts that have been done by the company. Company value according to Nurlela and Ishlahuddin (2008) can be reflected by market value.

\section{Development Of Hypotheses}

The value of the company to be a very important instrument because with high corporate value it will be followed by high shareholder wealth. The optimization of company value can be achieved through the implementation of Enterprise Risk Management (ERM). ERM disclosure information presented by the company will provide higher trust to users of information especially investors. Through ERM disclosure, company value can be maintained and enhanced (Hery, 2015). Hoyt and Liebenberg who conducted research in 2008 have proven that companies that implement ERM have a higher average company value compared with companies that do not implement ERM. Market participants will have a better perception of companies capable of performing high quality ERM disclosures (Baxter 2012). Companies that divide ownership and corporate management are susceptible to agency conflict. This condition will certainly lead to agency cost equity, so to overcome these conditions the company can apply the system of managerial ownership. Ningsih (2013) in his research explains that managers acting as shareholders will have a higher motivation in managing related companies in considering risks and improving their performance. In general, companies that tend to increase their value are able to disclose broader information with high managerial shareholding structures (Ramadhani and Hadiprajitno 2012). Based on the exposure, it can be formulated hypothesis as follows: 
H1: ERM Disclosure positively affects the value of the company

H2: Managerial ownership moderates the influence of ERM Disclosure on corporate value

\section{Research Methods}

Operational Definition of Variables

a. Independent variable

ERM disclosure is measured using the ERM disclosure index calculated as follows:

$$
E R M D I=\frac{\Sigma i j \text { Ditem }}{\Sigma i j \text { ADitem }}
$$

Information:

ERMDI : ERM Disclosure Index

¿ij Ditem : The Total Item of ERM Items Revealed

Sij Aditem : Total ERM Item Should Be Revealed

\section{b. Dependent variable}

The value of the firm as a dependent measurement ratio used is Tobin's Q value with the following formula.

$$
\text { Tobin's } Q=\frac{\text { MrS }+D}{\text { TA }}
$$

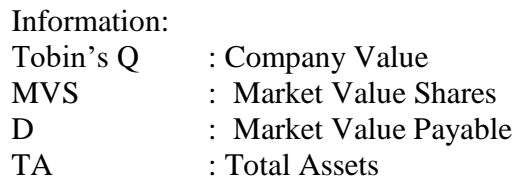

\section{c. Moderate variables}

The value of managerial ownership will be calculated using the percentage value (Wida 2014), with the following formula:

$$
\mathrm{KM}=\frac{\Sigma_{\mathrm{SM}}}{\Sigma_{\mathrm{SB}}} x 100 \%
$$

Information:

KM : Managerial Ownership

¿SM : Total Managerial Share

$\Sigma \mathrm{SB} \quad:$ Total Shares Outstanding 


\section{Sample}

The study population is a manufacturing company that publishes annual report during the observation period of 2014-2016. The sample was selected using the porposive sampling technique. In Table. 1 presented sample selection process.

Tabel 1.

Sample Selection Process

\begin{tabular}{clc}
\hline No & \multicolumn{1}{c}{ Sample Criteria } & $\begin{array}{c}\text { Total } \\
\text { Amount }\end{array}$ \\
\hline 1 & $\begin{array}{l}\text { Manufacturing companies } \\
\text { listed on the Indonesia Stock }\end{array}$ & 147 \\
2 & $\begin{array}{l}\text { Exchange period 2014-2016. } \\
\text { Manufacturing companies } \\
\text { publish financial statements for } \\
\text { the period 2014-2016. }\end{array}$ & $(11)$ \\
3 & $\begin{array}{l}\text { Manufacturing companies with } \\
\text { managerial ownership data for } \\
\text { the period 2014-2016. }\end{array}$ & $(117)$ \\
& $\quad \begin{array}{l}\text { Number of samples } \\
\text { Total observations (2014-2016) }\end{array}$ & 57 \\
\hline & Source: Data processed, 2018 &
\end{tabular}

Data analysis technique

The data collection method used to analyze ERM disclosure is content analysis through dichotomy data.

Descriptive statistics and Moderated Regression Analysis (MRA) with panel data regression models are used to analyze data with the following equation.

$$
N P=\alpha+\beta 1 E R M D I+\beta 2 E R M D I * K M+\varepsilon
$$

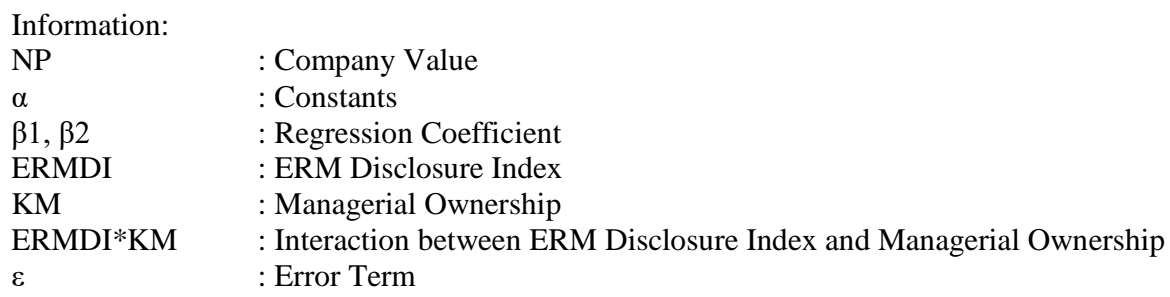

\section{Results}

Hypothesis testing this research using panel data regression. Panel data regression has three model approaches: Common-Constant (The Pooled OLS Method = PLS) method, Fixed Effect Model (FEM) method, and Random Effect Model (REM) method. The most appropriate model selection result through Chow or Likelihood Test Ratio test, Lagrange Multiplier (LM) test, and Hausman test is FEM model. Considering that the determinant value of FEM model shows $87 \%$ result but PLS model only $3 \%$ and REM model $0 \%$,. The result of 
Moderated Regression Analysis (MRA) analysis by using panel data regression model shown in Table 2 below

Tabel 2. Results of MRA analysis with FEM model panel data regression model

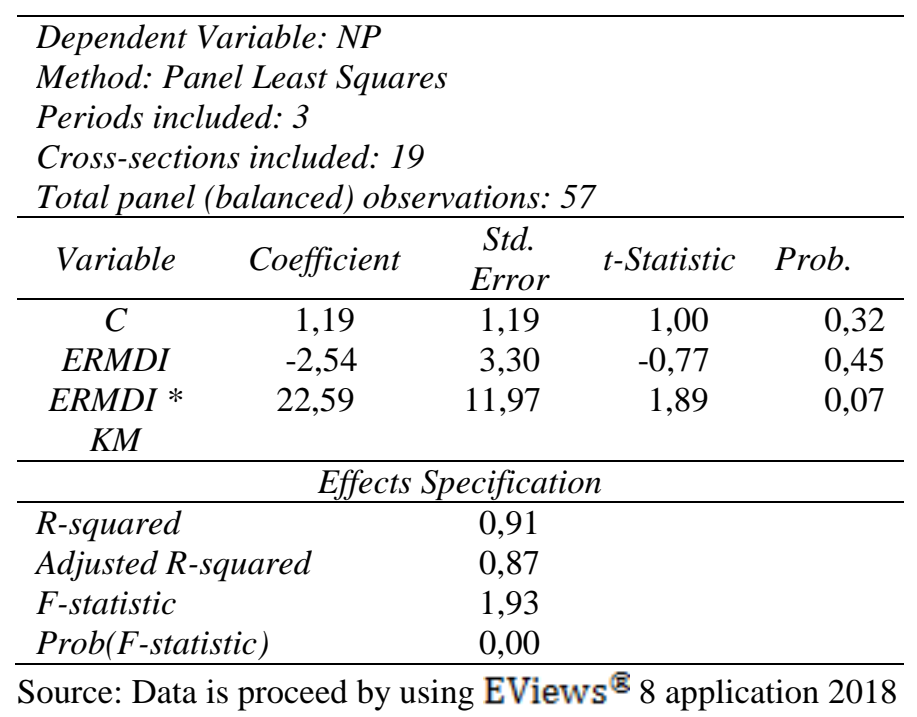

Based on the results in Table 3, the following equations are made.

$N P=1,19-2,54 E R M D I+22,59 E R M D I * K M+\varepsilon$

\section{Discussion}

\section{Influence of ERM Disclosure on company value}

ERM disclosure is important information for investors. ERM management that can be done well and disclosed to the public in the form of quality disclosure ERM will be responded positively by the stakeholders. Integrated ERM implementation is expected to support the achievement of corporate objectives (Charvin, 2014). But the test results show ERM disclosure does not affect the value of the company. These results support the research of Aditya and Prima (2017) which explains that ERM implementation has no effect on company value. Some previous researchers also found similar results that ERM had no significant effect on firm values such as research by Li et al. (2014), and Tahir \& Razali (2011).

Kartika and Nanik (2015) revealed that the consideration of investors in investing in Indonesia, especially the financial sector more consider other information than the implementation of an enterprise ERM. In addition, ERM implementation in the company is something that is integrated and can only be known the impact in the long term. This statement is in line with Beasley, Pagach \& Warr (2008) research that found that ERM applied by the company through an integrated communication within the company's internal environment will only be felt in the future. Besides, not all information about future corporate risks expressed by the company will be responded positively by investors even though the 
company has shown efforts in managing those risks. This statement is in accordance with the results of the study Abdullah et al. (2015).

\section{The relationship between ERM Disclosure and company value moderated by managerial ownership}

Agency theory emphasizes that companies whose proprietary systems and management systems are separated will be vulnerable to conflict when the interests of both parties are not aligned. Ross et al. (1999) quoted from Siallagan and Machfoedz (2006) states that the performance of corporate management can be improved through increased managerial ownership. The test results show that the effect of ERM disclosure on firm value cannot be strengthened by managerial ownership. Companies that have a managerial ownership system still do not encourage companies to conduct a wider ERM disclosure to increase value for the company. Besides that it was also found that the average managerial ownership of manufacturing companies in Indonesia is still very low. So with such a percentage rate, the authority to make decisions that will have a major impact on the company can not be done by the managers. Investors also judge that the more professional the managers of the company, not infrequently they will be more likely to ignore the company's goals and even will prioritize personal interests. Investors ultimately do not take into consideration the judgment of a company that has managerial ownership to decide to invest even if the company is conducting ERM disclosure. This research supports Larasati (2011), Samisi (2013), Primady (2015), Wiryani (2016), and Pratama (2016).

\section{Conclusions}

This study concluded that disclosures made by companies in the form of ERM disclosure did not affect the value of the company. The relationship between ERM disclosure to company value is also not able to be moderated by managerial ownership. Companies that have a managerial ownership system are still unable to encourage companies to conduct a wider disclosure ERM to increase company value.

\section{REFERENCES}

[1] J. C. Teas, R.K., \& McElroy, "Causal Attribution and Expectancy Estimates: A Framework for Understanding the Dynamics of Sales force Motivation," J. Mark. Res., vol. 50, pp. 75-86, 2003.

[2] S. Devi, "Pengaruh Enterprise Risk Management Disclosures dan Intelectual Capital Disclosure Pada Nilai Perusahaan,” J. Akunt. dan Keuang. Indones., vol. 14, no. 1, pp. 20-45, 2017.

[3] R. . \& A. P. L. Hoyt, "The Value of Enterprise Risk ManagementL Evidence from the U.S. Insurance Industry,” J. Risk Insur., vol. 78, no. 4, pp. 795-822, 2011.

[4] I. M. Tahir, "The Relationship Between Enterprise Risk Management (ERM) and Firm Value: Evidence from Malaysia Public Listed Comapanies," Int. J. Econ. Manag. Sci., vol. 1 , no. 2, pp. 32-41, 2011.

[5] G. . et all Bertinitti, "The Effect of The Enterprise Risk Management Implementation on The Firm Value of European Companies," 2013.

[6] A. M. et al Shukor, "Risk Management Disclosures: A Study on The Effect of Voluntary Risk Management Disclosures Toward Firm Value," J. Appl. Account. Res., vol. 16, no. 
3, pp. 400-432, 2015.

[7] R. et all Baxter, "Enterprise Risk Management Program Quality: Determinants , Value relevance and the Financial Crisis.," Contemp. Account. Res., vol. 30, no. 4, pp. 12641295, 2013.

[8] B. J. Fraser J \& Simkins, “Enterprise Risk Management: Today’s Leading Research and Best Practices for 